\title{
SUBSTITUSI SEBAGIAN RANSUM DENGAN TEPUNG TOMAT MERAH (Solanum lycopersicum $l$ ) TERHADAP PENAMPILAN PRODUKSI AYAM RAS PETELUR
}

\author{
Earvin M. Lengkong ${ }^{*}$, Jein Rinny Leke ${ }^{* *}$, Linda Tangkau ${ }^{* *}$, Srimalanshina Sane ${ }^{* *}$ \\ Fakultas Peternakan Universitas Sam Ratulangi, Manado \\ Email :earvinlengkong@ymail.com
}

\begin{abstract}
ABSTRAK
Tujuan dari penelitian ini adalah untuk mengetahui sejauh mana substitusi sebagian ransum dengan tepung tomat merah (solanum lycopersicum $l$ ) pada ayam ras petelur MB 402 berpengaruh terhadap penampilan produksi. Penelitian ini menggunakan ayam ras petelur fase layer yaitu umur 36 minggu sebanyak 100 ekor.Metode yang digunakan adalah Rancangan Acak Lengkap (RAL) dengan lima perlakuan dan lima ulangan setiap ulangan terdiri dari empat ekor ayam petelur. Perlakuan yang digunakan P0 : ransum basal tanpa tepung tomat; P1 : ransum basal $98 \%+$ $2 \%$ tepung tomat; $\mathrm{P} 2$ : ransum basal $96 \%+$ $4 \%$ tepung tomat; $\mathrm{P} 3$ : ransum basal $94 \%+6$ $\%$ tepung tomat; P4 : ransum basal $92 \%+8 \%$ tepung tomat. Variabel yang diteliti terdiri dari konsumsi ransum, produksi telur (HDP) dan konversi ransum. Data dianalisa menggunakan rancangan acak lengkap (RAL), apabila diantara perlakuan menunjukkan hasil yang berbeda sangat nyata akan dilanjutkan dengan Uji Jarak Berganda Duncan'S. Hasil penelitian menunjukan bahwa Subsitusi sebagian ransum tepung tomat merah dalam ransum tidak memberikan pengaruh nyata $(\mathrm{P}<0.05)$ terhadap konsumsi ransum dan konversi ransum, namun memberikan pengaruh sangat nyata $(\mathrm{P}>0.01)$ terhadap produksi telur (HDP). Maka dapat disimpulkan bahwa Substitusi Sebagian ransum dengan tepung tomat merah (Solanum Lycopersicum $L$ ) dengan level $8 \%$ pada ayam ras petelur memberikan respons yang baik terhadap konsumsi ransum, produksi Telur dan Konversi Ransum.
\end{abstract}

Kata kunci : Ayam petelur, Tepung Tomat Merah,

\footnotetext{
*Alumni Fakultas Peternakan

** Jurusan Produksi Ternak
}

\begin{abstract}
SUBSTITUTION OF SOME RATION WITH RED TOMATOES (Solanum lycopersicum l) TOWARDS LAYING HENS PRODUCTION APPEARANCE. The purpose of this study was determine to extent the substitution of some ration with red tomatoes flour (solanum licopersicum L) on MB 402 laying hens react to the production appearance. This study used chicken laying phase layer that is aged 36 weeks of treatment as much 100 individual invitation. The used method is a field experiment using a CRD with five treatments and five replications. Each replication consist of four laying hens. The treatment used P0 : basic ration with out red tomatoes flour, $\mathrm{P} 1: 98 \%$ of basic ration $+2 \%$ of red tomatoes flour, P2: $96 \%$ of basic ration $+4 \%$ of red tomatoes flour, P3: $94 \%$ of basic ration $+6 \%$ of red tomatoes flour, P1: $92 \%$ of basic ration $+8 \%$ of red tomatoes flour. The variables studied are based on feed consumtion, egg production (HDP), and feed conversion. Data were analyzed ising a CRD, if the treatments showed highly significant result, it will be test using multiple range test by Duncan. The results showed that substitution of some ration with red tomatoes flour on feeding hems doesnot provide significant effect $(\mathrm{P}<0.05)$ towards feed consumtion and feed conversion, but giving a significant effect $(\mathrm{P}>0.01)$ towards egg production (HDP). It can be concluded that the substitution of some ration with red tomatoes flour (solanum licopersicum $L$ ) with the number $8 \%$ on laying hens gave a good response on feed consomtion, egg production, and conversion ration.
\end{abstract}

Keywords: Laying hens, Red Tomatoes Flour 


\section{PENDAHULUAN}

Ayam telah dikembangkan sangat pesat di setiap negara. Sentra peternakan ayam petelur sudah dijumpai di seluruh pelosok Indonesia.Ayam petelur sudah lama dikenal di masyarakat dan diusahakan sebagai usaha sampingan maupun usaha peternakan. Hal ini dikarenakan ayam petelur mempunyai potensi besar untuk dikembangkan sebagai usaha peternakan karena memiliki sifatsifat dan kemampuan yang menguntungkan yaitu telur mempunyai nilai gizi dan rasa yang lezat.

Telur merupakan produk peternakan yang memberikan sumbangan besar bagitercapainya kecukupan gizi masyarakat (Sudarmono, 2003). Sebutir telur mempunyai gizi yang cukup sempurna karena mengandung zat-zat gizi yang lengkap dan mudah dicerna. Telur ayam ras secara fisik terdiri dari $10 \%$ kerabang (kulit telur, cangkang), 60\% putih telur dan 30\% kuning telur (Sarwono dkk, 1995). Menurut North \& Bell (1990) kandungan dari zat-zat makanan kuning telur yaitu protein $17,5 \%$, lemak $32,5 \%$.

Ayam petelur kemudian dijadikan sebagai ayam unggulan dalam produksi telur dan persilangan genetik ayam lokal sehingga memperbaiki mutu genetik ayam-ayam yang ada di Indonesia.
Dengan demikian kebutuhan akan telur bisa dipenuhi.

Dalam upaya peningkatan produksi telur, ternak unggas harus diberi pakan sesuai kebutuhan dan mengandung gizi sesuai rekomendasi. Produksi telur sangat erat kaitannya dengan konsumsi pakan, konversi pakan. Pemberian pakan yang baik tentunya akan berpengaruh terhadap produksi telur, konsumsi pakan, dan juga angka konversi dari pakan yang diberikan. Pakan dalam usaha peternakan unggas memiliki peranan pokok yang perlu mendapat perhatian selain bibit dan manajemen.

Tomat yang biasa digunakan sebagai minuman jus dan sebagainya dapat dimanfaatkan sebagai bahan tambahan dalam ransum ayam petelur. Selain mudah didapat, kandungan yang ada dalam buah tomat dapat dimanfaatkan dalam ransum. Dibalik warnanya yang merah, buah tomat banyak mengandung zat gizi, salah satunya adalah vitamin C. Kandungan vitamin $\mathrm{C}$ dalam $100 \mathrm{gr}$ buah tomat masak yaitu $40 \mathrm{mg}$. Buah tomat mempunyai daya simpan yang tidak dapat bertahan lama, lebih dari 3 hari akan busuk, selain itu bila mutunya sudah tidak bagus atau tidak segar harga buah tomat juga akan murah.

Tomat, baik dalam bentuk segar maupun olahan, memiliki komposisi zat gizi yang cukup lengkap dan baik. 
Buah tomat terdiri dari 5 - $10 \%$ berat kering tanpa air dan $1 \%$ kulit dan biji. Jika buah tomat dikeringkan, sekitar 50\% dari berat keringnya terdiri dari gula-gula pereduksi (terutama glukosa dan fruktosa), sisanya asam-asam organik, mineral, pigmen, vitamin dan lipid.

Nobakht et al. (2007) menyatakan bahwa pemberian level Dried Tomato Pomace (limbah jus tomat kering)pada kandungan serum dan kolestrol dalam kuning telur tidak memberikan pengaruh yang yang nyata $(\mathrm{P}>0,05)$ terhadap perlakuan. Dari hasil penelitian tersebut menyimpulkan bahwa Dried Tomato Pomace dapat digunakan sebagai bahan pakan ayam petelur sampai pada level 10 $\%$ dari total pakannya tanpa mempengaruhi performans dan produksi telurnya. Aynan et al. (2004) melaporkan bahwa tomat kering berbentuk tepung dapat digunakan sebagai bahan pakan untuk ayam pedaging dengan level pemberian $5 \%$ per kg pakan dengan crude protein 20\% dan ME $3125 \mathrm{kkal} / \mathrm{kg}$. Laszalo et al. (2005) melaporkan bahwa senyawa likopen sebagai hasil proses pengolahan tomat dan turunannya bisa dijadikan dalam bahan pakan ternak unggas. Dotas et al. (2000) melaporkan bahwa penambahan tomat kering tidak memberikan perbedaan yang nyata terhadap produksi telur, konsumsi pakan, bobot telur, tetapi memberikan perbedaan pengaruh terhadap warna kuning telur. Kang et al. (2003) menyatakan bahwa Dried Pomace Tomato (hasil samping pengolahan tomat kering) merupakan sumber zat makanan yang sangat baik khususnya sebagai sumber vitamin $E$ (tokoferol) yang digunakan sebagi antioksidan dalam pemeliharaan ayam pedaging.

Berdasarkan uraian diatas, maka penelitian ini bertujuan untuk mengetahui substitusi sebagian ransum dengan tepung tomat berpengaruh terhadap konsumsi pakan produksi telur dan konversi pakan.

\section{MATERI DAN METODE PENELITIAN}

Materi yang digunakan dalam penelitian ini adalah ayam ras petelur fase layer yaitu umur 36 minggu sebanyak 100 ekor. Kandang yang digunakan dalam peneletian ini adalah kandang battery dan setiap unit kandang ditempati 4 ekor ayam. Bahan pakan yang digunakan dalam penelitian ini yaitu jagung, dedak, tepung ikan, $\mathrm{CaCO} 3$, konsentrat $\mathrm{Cal} 9.36$ dan tepung tomat.

Metode penelitian yang digunakan adalah Rancangan Acak Lengkap dengan 5 perlakuan dan 5 ulangan dan tiap ulangan berisi 4 ekor ayam petelur MB 402 . 
Tabel 1. Komposisi Zat Gizi Tepung Tomat

\begin{tabular}{lr}
\hline Zat Gizi & Tepung Tomat \\
\hline Protein & $16,73^{*}$ \\
Lemak & $1,53^{*}$ \\
Serat kasar & $30,94^{*}$ \\
Calsium & $0,98^{*}$ \\
Phospor & $1,20^{*}$ \\
ME (Kkal) & $2416^{* *}$ \\
\hline
\end{tabular}

*) Berdasarkan Hasil Analisa Balai Riset dan Standarisasi Industri Manado 2014

**) Hasil Analisa Laboratorium Ilmu dan Teknologi Pakan Fakultas Peternakan IPB 2014

Tabel 2. Komposisi Ransum Percobaan

\begin{tabular}{lccccc}
\hline \multirow{2}{*}{ Bahan Makanan } & \multicolumn{5}{c}{ Jumlah $(\%)$} \\
\cline { 2 - 6 } & $\mathrm{R}_{0}$ & $\mathrm{R}_{1}$ & $\mathrm{R}_{2}$ & $\mathrm{R}_{3}$ & $\mathrm{R}_{4}$ \\
\hline Ransum Basal & 100 & 98 & 96 & 94 & 92 \\
Tomat & 0 & 2 & 4 & 6 & 8 \\
\hline Total & 100 & 100 & 100 & 100 & 100 \\
\hline
\end{tabular}

Tabel 3. Komposisi Zat-zat Makanan Ransum Percobaan

\begin{tabular}{lccccc}
\hline \multirow{2}{*}{ Komposisi Zat-zat Makanan } & \multicolumn{5}{c}{ Persentase (\%) } \\
\cline { 2 - 6 } & $\mathrm{R}_{0}$ & $\mathrm{R}_{1}$ & $\mathrm{R}_{2}$ & $\mathrm{R}_{3}$ & $\mathrm{R}_{4}$ \\
\hline Protein & 17,49 & 17,47 & 17,45 & 17,44 & 17,42 \\
Lemak & 6,63 & 6,61 & 6,59 & 6,57 & 6,56 \\
Serat kasar & 4,31 & 5,41 & 6,5 & 7,24 & 8,69 \\
Ca & 2,76 & 2,75 & 2,69 & 2,66 & 2,56 \\
$\mathrm{P}$ & 1,42 & 1,16 & 1,42 & 1,41 & 1,40 \\
ME (Kkal) & 2766 & 2759 & 2752 & 2745 & 2738 \\
\hline
\end{tabular}

Keterangan : Hasil perhitungan berdasarkan Patrick and Schaaible (1982).

Sedangkan penggunaan tepung tomat sesuai dengan perlakuan adalah : $\mathrm{P} 0=$ pakan tanpa menggunakan tepung tomat, $\mathrm{P} 1=$ Pakan basal $98 \%+2 \%$ tepung tomat, $\mathrm{P} 2=$ pakan basal $96 \%+4 \%$ tepung tomat, $\mathrm{P} 3=$ Pakan basal $94 \%+6$ $\%$ tepung tomat, $\mathrm{P} 4=$ pakan basal $+8 \%$ tepung tomat. Pakan yang digunakan dapat dilihat pada Tabel 1, 2, dan 3 
Variabel yang diamati yaitu :

1. Konsumsi Ransum : dihitung dengan cara menimbang sejumlah pakan yang diberikan (gram) dikurangi sejumlah pakan yang tersisa (gram) yang dilakukan setiap 24 jam sekali (Anggorodi, 1985).

2. Konversi Ransum: Dihitung menurut Olgun et al (2009) sebagai berikut :

Konversi ransum

$=\frac{\text { Konsumsi ransum }\left(\frac{\mathrm{g}}{\text { ekor }} / \text { hari }\right)}{\operatorname{Egg~mass~}\left(\frac{\mathrm{g}}{\text { ekor }} / \text { hari }\right)}$

3. Produksi Telur (HDP): Presentase dari total telur yang di produksi oleh sejumlah ayam dalam kurun waktu tertentu (Dadang, 2006)

Analisis Data

Dihitung secara statistik dengan menggunakan analisis ragam rancangan acak lengkap (RAL). Apabila terdapat perbedaan diantara perlakuan dilakukan uji lanjut dengan DMRT (Duncan's Multiple Range Test) menurut Steel and Torrie (1994).

\section{HASIL DAN PEMBAHASAN}

Pengaruh penggunaan Substitusi sebagian ransum dengan tepung tomat merah (Solanum lycopersicum $l$ ) pada ayam ras petelur MB 402 terhadap konsumsi pakan, produksi telur (HDP),konversi ransum dapat dilihat pada Tabel 4.

\section{Pengaruh Perlakuan Terhadap} Konsumsi Ransum

Konsumsi pakan adalah banyaknya pakan yang diberikan dikurangi sisa pakan atau pakan yang menunjukkan rata- rata jumlah pakan yang dikonsumsi seekor ayam sesuai periode pemeliharaan (Scott et al., 1992). Hasil konsumsi pakan (Tabel 4) dari tertinggi hingga terendah yaitu P3 : 111,56 ; P4 : 110,76 ; P0 : 110,88 ; P1 : 108,99; dan P2 : 109,97 gram/ekor/hari.Analisis ragam konsumsi pakan menunjukkan bahwa perlakuan tidak memberikan pengaruh yang nyata $(\mathrm{P}$ $>0,05)$ terhadap konsumsi Pakan. Angka ini lebih rendah dengan konsumsi pakan ayam petelur yang didapat oleh Nuraini dkk (2008) yaitu 114,79 gram/ekor/hari dengan pemberian $60 \%$ onggok dan $40 \%$ ampas tahu yang difermentasi dengan Neuspora crassa pada ayam petelur umur 28 - 36 minggu. Hal ini disebabkan oleh kandungan serat kasar tepung tomat cukup tinggi yaitu 30,94 \%. Bahri (2008) menyatakan bahwa serat kasar yang tinggi tidak hanya sulit dicerna tetapi juga menyebabkan beberapa zat makanan 
Tabel 4. Pengaruh Perlakuan Terhadap konsumsi ransum, produksi telur, dan konversi ransum

\begin{tabular}{cccc}
\hline \multirow{2}{*}{ Perlakuan } & \multicolumn{3}{c}{ Variabel } \\
\cline { 2 - 4 } & $\begin{array}{c}\text { Konsumsi Ransum } \\
(\text { Gram/Ekor/Hari })\end{array}$ & $\begin{array}{c}\text { Produksi Telur } \\
(\%)\end{array}$ & $\begin{array}{c}\text { Konversi Ransum } \\
(\text { Konsumsi/Egg Mass) }\end{array}$ \\
\hline P0 & $110.882 \pm 4.48$ & $87.058 \pm 1.97^{\mathrm{a}}$ & $2.01 \pm 0.06$ \\
P1 & $108.994 \pm 5.12$ & $87.058 \pm 1.89^{\mathrm{a}}$ & $2.05 \pm 0.05$ \\
P2 & $109.968 \pm 5.32$ & $91.078 \pm 4.64^{\mathrm{b}}$ & $2.10 \pm 0.07$ \\
P3 & $111.56 \pm 4.88$ & $92.684 \pm 2.18^{\mathrm{b}}$ & $2.15 \pm 0.04$ \\
P4 & $110.762 \pm 4.65$ & $94.382 \pm 2.15^{\mathrm{b}}$ & $2.09 \pm 0.04$ \\
\hline
\end{tabular}

Keterangan : Superskrip yang berbeda menunjukkan berbeda sangat Nyata ( $\mathrm{P}<0,01$ )

terikut keluar bersama eksektra.

Peningkatan penggunaan serat kasar berpotensi pula menurunkan konsumsi pakan karena semakin tinggi serat kasar menyebabkan pakan bersifat bulky sehingga unggas tidak dapat mengkonsumsi pakan dalam jumlah yang mencukupi akibat dari keterbatasan tembolok (Samli et al., 2006).

Wahju (1997) menambahkan bahwa faktor utama yang mempengaruhi konsumsi pakan adalah kandungan energy metabolisme dalam pakan serta serat kasar yang tinggi, tidak dapat dimanfaatkan oleh unggas karena unggas tidak mempunyai enzim yang dapat mencerna serat kasar. Kualitas pakan didalam memformulasi pakan perlu diperhatikan agar pakan yang telah diformulasikan itu mampu diperoleh ternak yang bersangkutan dan jumlah zatzat makanan yang dibuthkan dapat dipenuhi karena masing-masing ternak mempunyai keterbatasan dalam mengkonsumsi pakan (Siregar, 1980).

\section{Pengaruh Perlakuan Terhadap Produksi Telur (HDP)}

HDP merupakan salah satu ukuran produktivitas dari ayam yang diproduksi dengan membagi jumlah telur dengan jumlah ayam saat itu (Amrullah, 2003). Hasil pengamatan tertinggi hingga terendah yaitu P4 94,38; P3 92,68; P2 91,078; P1 87,06 dan P0 87,06. Hasil analisis ragam HDP menunjukkan bahwa perlakuan berpengaruh sangat nyata $(\mathrm{P}<0,01)$ terhadap HDP. Hasil analisis ragam menunjukkan bahwa perlakuan dapat meningkatkan produksi telur ayam ras dan untuk mengetahui perlakuan yang paling berpengaruh makan dilanjutkan dengan Uji Duncan's.Hasil uji Duncan's menunjukkan bahwa penambahan tepung tomat sebanyak 4\% (P2), 6\% (P3), 8\% (P4) merupakan perlakuan yang dapat meningkatkan HDP. 
Nobakht et al. (2007) menyatakan bahwa pemberian level Dried Tomato Pomace (limbah jus tomat kering) berturut-turut sebesar 0,5 7,5 dan $10 \%$ dari total pakan memberikan perbedaan pengaruh yang nyata $(\mathrm{P}>0,05)$ terhadap produksi telur, bobot telur, egg mass dan bobot cangkang telur pada ayam petelur strain Hy-Line umur 65-73 minggu. Amrullah (2003) menyatakan bahwa faktor utama yang mempengaruhi produksi telur adalah jumlah pakan yang dikonsumsi dan kandungan zat makanan dalam pakan. Rasyaf (1992) menyatakan bahwa produksi telur dipengaruhi oleh konsumsi ransum terutama protein. Anggorodi (1994) menambahkan bahwa faktor makanan yang mempengaruhi produksi telur adalah kandungan protein dari makanan tersebut.

\section{Australianingrum}

menunjukkan bahwa produksi telur sangat dipengaruhi oleh tingkat protein dalam pakan. Hal yang sama juga dipaparkan oleh North and Bell (1990) bahwa jumlah pakan yang dikonsumsi berpengaruh terhadapa produksi ternak, dimana konsumsi pakan yang tinggi akan menghasilkan produksi yang tinggi pula. Penggunaan tepung tomat samapi $8 \%$ dalam ransum memiliki palatabilitas yang baik sehingga tidak menyebabkan jumlah konsumsi ransum. Ransum yang mengandung tepung tomat menghasikan aroma wangi yang dapat merangsang ayam untuk mengkonsumsi sehingga tidak menyebabkan penurunan konsumsi ransum. Sejalan dengan pendapat Amrullah (2003) bahwa penerimaan unggas terhadap makanan dipengaruhi oleh tekstur, rasa, dan bau. Kandungan serat kasar yang tinggi pada tepung tomat tidak menggangu ayam petelur sehingga ketersediaan protein dan energy metabolis tidak mempengaruhi kecepatan aliran bahan makanan dalam saluran pencernaan (Budiansyah dkk, 2003). Fakta tersebut menunjukkan bahwa konsumsi protein dan energy dari kelima perlakuan sudah memenuhi kebutuhan untuk memproduksi satu butir telur.ayam pada masa awal bertelur membutuhkan energi dan protein untuk hidup pokok, pertumbuhan, dan produksi telur. Masih adanya pertumbuhan pada masa tersebut menyebabkan protein dan energi yang dikonsumsi cenderung digunakan untuk hidup pokok, pertumbuhan dan produksi telur bukan untuk peningkatan bobot telur. Hal tersebut memberi suatu ketetapan bahwa penggunaan tepung tomat sampai taraf 8 $\%$ tidak memberikan efek negatif terhadap ayam petelur dan aman untuk dikonsumsi. 


\section{Pengaruh Perlakuan Terhadap}

\section{Konversi Ransum}

Konversi pakan dihitung setiap minggu dengan cara membandingkan jumlah pakan (g) yang dikonsumsi dengan massa telur (g/ekor/hari) setiap minggu. Hasil pengamatan (Tabel 4) dari tertinggi hingga terendah yaitu P3 2.15, P2 2,10, P4 2,09, P1 2,05 dan P0 2,01. Analisis ragam konversi pakan menunjukkan bahwa perlakuan berpengaruh tidak berbeda nyata $(\mathrm{P}>$ 0,05) terhadap konversi pakan. Konversi ransum dapat digunakan sebagai gambaran koefisien produksi, semakin kecil nilai konversi semakin efisien penggunaan ransum dan demikian sebalikknya.

Nilai konversi ransum yang disajikan pada Tabel 4 menunjukkan rataan pakan yang paling effisien dan ekonomis diperoleh pada perlakuan P0 yaitu 2,01. Konversi pakan antara ransum perlakuan P1 2,05 dan P4 2,09. Hal ini menunjukkan bahwa P0 memberikan respon produksi telur dan konversi pakan yang lebih baik dibandingkan dengan P1 dan P4. Angka konversi ransum pada penelitian ini lebih baik dibandingkan P2 2,10 dan P3 2,15. Anggorodi (1985) menyatakan bahwa indeks konversi ransum hanya akan naik bila hubungan antara jumlah energy dalam formula dan kadar protein telah disesuaikan secara teknis, berarti ransum yang digunakan pada penelitian ini lebih effisien karena semakin kecil angka konversi ransum semakin baik, karena penggunaan ransum semakin effisien karena banyaknya yang terkonsumsi. Konversi ransum berhubungan dengan konumsi ransum dan pertambahan produksi ayam. Rata - rata konsumsi ransum selama penelitian tiap perlakuan selama penelitian adalah P3 (111,56 gram/ekor/hari, P0 110,88 gram/ekor/hari, P4 110,76 gram/ekor/hari, P2 109,96 gram/ekor/hari dan P1 108,99 gram /ekor/hari. Konsumsi ransum pada penelitian ini adalah relatif sama dan termanfaatkan oleh ayam petelur dan produksi telur cukup tinggi yaitu P4 94,38 $\%, \mathrm{P} 3$ 92,68 \%,P2 91,07 \% lebih tinggi dibandingkan P1 87,05 \% dan P0 87,05\%. Jadi tinggi rendahnya konversi ditentukan oleh keseimbangan antara energy metabolisme dengan zat zat nutrisi lainnya terutama protein dan asam asam aminonya (Anggorodi, 1985) ditambahkan pula oleh Rasyaf (1994), bahwa konversi ransum menunjukkan tingkat effisiensi penggunaan ransum untuk ternak, dan menentukan nilai ekonomis setiap penggunaan ransum yang erat kaitannnya dengan biaya produksi. 
Konversi pakan yang tinggi pada pakan lebih disebabkan karena konsumsi pakan yang rendah yang menyebabkan kecukupan asupan zat makanan ayam untuk memproduksi telur menjadi sedikit lebih rendah. Apabila dilihat dari besarnya angka konversi pakan yang diperoleh semua ransum perlakuan dalam penelitian ini, dapat dikatakan masih dalam batas normal berkisar antara 2,01-2,15. Nuraini dkk., (2008) yang mendapatkan konversi ransum ayam petelur sebesar 2,55 dengan pemberian $60 \%$ onggok dan $40 \%$ ampas tahu yang difermentasi dengan Neurospora crassa pada ayam petelur berumur $28-36$ minggu. Scott et al., (1982) bahwa konversi pakan ayam petelur selama produksi telur pertama maupun kedua berkisar antara 2,0 $-3,0$.

\section{KESIMPULAN}

Substitusi Sebagian Ransum Dengan Tepung Tomat Merah (Solanum Lycopersicum $L$ ) dengan level $8 \%$ pada Ayam Ras Petelur MB 402 memberikan respon yang baik terhadap konsumsi ransum, konversi ransum, produksi telur (HDP).

\section{DAFTAR PUSTAKA}

Amrullah, I. K. 2003. Nutrisi Ayam Petelur. Lembaga Satu Gunung Budi. Bogor.

Amrullah, I. K.2004. Nutrisi Ayam Petelur Penebar Swadaya. Jakarta.

Anggorodi.1994. Ilmu Makanan Ternak Umum. PT. Gramedia. Jakarta.

Anggorodi.,1985. Kemajuan mutakhir dalam ilmu makanan ternak unggas.UI. Perss.I

Australiananingrum, Y. 2005. Pengaruh Penggunaan Daun Singkong (Manihot Esculenta) Pada Ransum Ayam Petelur Terhadap Kualitas Telur.Skripsi Jurusan Produksi Ternak Fakultas Pertanian Universitas Sebelas Maret Surakarta.Diakses tanggal 25 Juni 2011.

Aynan, V., and S. Aktan.2004. Potensial Use of Dried Tomato Pomace in Broiler Chicken Diets. Journal of Animal Production, Vol 45 No. 1 (19-20).

Bahri, S dan Rusdi. 2008. Evaluasi Energi Metabolis Pakan Lokal Pada Ayam Petelur. http://jurnal.untad.ac,id/jurnal.inde x.php/AGROLAND/article/view/1 63/135. Diakses pada tanggal 10 Februari 2014.

Budiansyah, A. 2003. Pengaruh penggunaan silase tepung daging keong mas (pomaceae sp) dalam ransum terhadap pertumbuhan dan karkas ayam broiler. J. Ilmiah 
Ilmu-ilmu Peternakan.6 (4) :227-234.

Dotas, D. S. Zamanidis; N. J. Balios. 2000. Effect of Dried Tomato Pulp On The Performance and Egg Traits of Laying Hens. British Poultry Science.Volume 40, Issue 05 December 2000, 695-697 Animal Physiology Embriology, Meat and Poultry.

Kang, D. K., S. I. Kim, C. H. Cho, Y. H. Yim, \& H. S. Kim. 2003. Use of lycopene, An antioxidant carotenoid, in laying hens for egg yolk pigmentation. AsianAust.J.Anim. Sci. 16(12):17991803.

Laszlo, B. Zsuzsanna, K. Balazs, R. Aannamaria, K and S. Csaba. 2005. Studies on Effect of Lycopene in Poultry (hens and quil). Department of Animal Physiolgy and Health. University St Istvan. Ungaria. ISAH. 2005 - Vol 2 Warsaw, Poland.

Nobakht, A and A. R. Safamehr. 2007. The Effects on Inclussion Different Levels of Dried Tomato Pomace in Laying Hens Diets on Performance and Plasma and Egg Yolk Cholesterol Contents. Department of Animal and Veterinary Advances 6 (9) : 1101-1106, 2007.

North and Bell. 1990. Commercial Chicken Production Manual, New York. J. Cent. Eur. Agric. 7(1):135140.

Nuriani, Sabrina and S.A. Latif. 2008. Performa Ayam dan Kualitas Telur Yang Menggunakan Ransum

Sudarmono, A. S., 2003. Pedoman Pemeliharaan Ayam Petelur. Kanisius.

\begin{abstract}
Menggandung Ogok Fermentasi Dengan Neurospora Crassa. Jurnal Media Peternakan 31(3): 195-202.
\end{abstract}

Patrick, H. and P.J. Schaible. 1980. Poultry Feed and Nutrition. 2nd Ed. Ani Pub.Inc., Westport, Connecticut.

Rasyaf, M. 1992. Produksi dan Pemberian Ransum Unggas. Kanisius.

Rasyaf, M. 1994. Makanan Ayam Broiler. Yayasan Kanisius, Yogyakarta.

Samli H.E., N. Senkpylu, H. Akyurek, and A. Agma. 2006 Using Rice Brain In Layer Diets.

Sarwono, B. A. Murtidjo dan A. Daryanto. 1995. Pengawetan dan Pemanfaatan Telur. PT. Penebar Swadaya, Jakarta.

Scott, M. L. Neheim, M., and Young, R. J. 1982. Nutrition of the Chiken. $3^{\text {rd }}$ ed. M. L. Scott and Associates Publisher Ithaca, New York.

Scott, M. L., Nesheim, M., and Young, R. J. 1992.Nutrition of The Chicken. Fifth Ed. Scott, M. L. And Associates. Ithaca. New York.

Siregar. A. P. 1980. Tehnik Beternak Ayam Pedaging di Indonesia. Merdie Group. Jakarta.

Steel RGD, Torrie JH. 1994. Prinsip dan prosedur Statistika (Suatu Pendekatan Biometrik). Terjemahan : Bamabang Sumantri. Jakarta: Gramedia Pustaka Umum. 
Wahyu, J. 1978. Cara Pemberian Dan Penyusunan Ransum Ayam. Fakultas Peternakan. Institut Pertanian Bogor. Feed Formulating Pattern for Growing Chicks Based on Nitrogen Retention, Nitrogen Consumed, and Metabolism Energy. Disertation. Institut Pertanian Bogor, Bogor.1992. Ilmu Nutrisi Unggas. Cetakan ke-3. Gadjah Mada University Press, Yogyakarta.

Wahyu, J. 1988. Ilmu Nutrisi Unggas.

Cetakan kedua. Gadjah Mada Press. Jogja.
Wahyu, J. 1997. Ilmu Nutrisi Unggas. Gaja Mada University Press, Yogyakarta. 